\title{
MOUNT RUAPEHU, NEW ZEALAND: OBSERVATIONS ON ITS CRATER LAKE AND GLACIERS
}

\author{
By N. E. ODELL
}

(Department of Geology, University of Otago, Dunedin, N.Z.)

\begin{abstract}
Anstract. Mt. Ruapehu, the highest summit in the North Island of New Zealand, is a semi-dormant volcano, whose crater lake was responsible for the flood that caused the disastrous railway accident on Christmas Eve, 1953 . Since the last eruption of 1945 , when mostly ash was ejected, the crater lake that subsequently formed has been contained by a barrier partly composed of lava and partly of névé and ash. It was the breaking through of the latter weaker portion of the dam that was responsible for the flood of mud and boulders which descended via the Whangaehu Glacier and struck the railway 25 miles $(40 \mathrm{~km}$.) distant. There is no evidence of eruptive activity having been the cause of the outbreak. During three ascents of the mountain, observations were made of the glaciers, which have been in a state of gradual shrinkage over a number of years. But during the past Summer-a season of exceptional dryness - the process of ablation and wastage has been greatly accelerated, so that immense areas of rock and ash have freshly emerged, and crevasses and dirt-ridges have taken the place of smooth névé or glacier surfaces.
\end{abstract}

Zusammenfassung. Mt. Ruapehu, der höchste Gipfel auf der North Island Neuseelands, ist ein halb schlummernder Vulkan, dessen Krater-See für die Flut verantwortlich war, die das unheilvolle Eisenbahnunglück am Heilig Abend 1953 verursachte. Seit dem letzten Ausbruch im Jahre 1945 , bei dem hauptsächlich Asche ausgestossen wurde, war der Krater-See, der sich nachfolgend bildete, von einer Barriere umfasst, die teilweise aus Lava und teilweise aus Firn und Asche bestand. Es war das Durchbrechen des letzteren schwächeren Teiles des Dammes, das für die Flut von Schlamm und Geröll verantwortlich war, die über den Whangaehu Gletscher herabfiel und die Eisenbahn $40 \mathrm{~km}$ entfernt traf. Es liegt kein Beweis vor, dass eruptive Aktivität die Ursache gewesen wäre. An Hand von drei Besteigungen des Berges waren Beobachtungen der Gletscher, die sich seit mehreren Jahren in einem Zustand allmählichen Einschrumpfens befinden, vorgenommen worden. Doch während der letzten Sommer Saison, die aussergewöhnlich trocken war, war der Ablations- und Schrumpfungs-Vorgang stark beschleunigt worden, so dass enorme Felsen- und Asche-Gebiete neuerdings zum Vorschein kamen, und Gletscherspalten und Schmutzfurchen an Stelle des glatten Firnes und der glatten Gletscheroberfläche zu sehen sind.

ON Christmas Day 1953 the world heard that a railway accident, unprecedented in the history of New Zealand, had occurred the previous evening, when the Wellington-Auckland express, just north of Tangiwai, crashed through the bridge over the Whangaehu River*-then a raging torrent-involving a total casualty list of $\mathrm{I}_{5} \mathrm{I}$ persons. This river has its source in the small Whangaehu Glacier that lies high on the south-eastern flank of the crater of Ruapehu, New Zealand's highest volcanic summit, which is situated in the North Island. Actually the crater is composite, and consists of an outer rim, enclosing an area of about a mile and a half long from north to south and half a mile wide, within which, at the southern end, is an inner volcanic cone with a central crater occupied by a lake. The latter is nearly circular and approximately $600 \mathrm{yd}$. $\left(54^{8} \mathrm{~m}\right.$.) across, whilst permanent fields of névé fill the depression between the inner cone and the outer rim on the north, west and south, and form ice cliffs in places along the border of the lake. On the east side of the lake rises a cone of scoriae and ash, culminating in Cinder Peak (Peretini), often called the Pyramid, whose outer slope falls steeply to the Whangaehu Glacier. Ruapehu's highest point, Tahurangi, $9175 \mathrm{ft}$. (2795 m.), is situated on the crater rim to the southward, and overlooks the lake. It was during what has been claimed to be the first complete ascent of the mountain in 1879 by George Beetham and Joseph P. Maxwell, of Wellington, that this crater lake was discovered, and surprisingly found to be hot! 1 On only two subsequent occasions has it been reported as frozen over, for usually it is warmed by volcanic vapours from below and bubbles can be seen to rise, while at times it has been observed steaming strongly. Moreover, in the interval since the first recorded visit by Beetham and Maxwell, there have occurred a number of eruptions which have ejected clouds of steam, gas or ash, and have left mud and stones scattered on the surrounding parts of the mountain. Quite recently (October 1954) the temperature of the lake water was found by Mr. J. Healy (Government vulcanologist) to be $39^{\circ} \mathrm{C}$., and he reported that bubbles, probably of gas, were being emitted towards the centre of the lake, about the position 
of the vent of the 1945 eruption, cited below. This information was obtained subsequent to an aerial reconnaissance, and a report that clouds of steam were rising and masking the surface of the lake itself-possibly a prelude to further eruption.

There is interesting evidence of variation in depth of the crater, and therefore of the depth of the lake in the recent past. At the time of the great eruption of Ruapehu in 1945 , a mass of molten lava rose to form first an island in the lake (Fig. r, p. 599), and later to occupy the whole floor of the crater. This lava plug, or "tholoid," was subsequently withdrawn, or blown out by explosion, and a pit of about $1000 \mathrm{ft}$. $(305 \mathrm{~m}$.) resulted, which was eventually filled up with water. In r950, however, an adventurous party of the New Zealand Canoeing Association ascertained that the greatest depth of the re-formed lake was $264 \mathrm{ft}$. $(70 \mathrm{~m}$.) at the point of principal eruptive activity in 1945; whilst soundings over much of the bottom elsewhere indicated anything from 60 to I $30 \mathrm{ft}$. ( $18-40 \mathrm{~m}$.). Since the Tangiwai disaster, further enterprising canoeists, carrying their craft to the top of the mountain, have again embarked on the foaming waters of the crater lake, and they have recorded approximately the same depths as previously. However, as Mr. J. H. Rose has stated, ${ }^{2}$ records go to show that in the years following the 1945 eruption the lake waters must have gradually risen until they were about $25 \mathrm{ft} .(7.6 \mathrm{~m}$.) or more above their old level. That they remained at this level for some time is indicated by beaches which were cut in the volcanic material round the lake in many places. In the north-west corner of the lake there was a dry bay in the ice cliffs where the water in rising $25 \mathrm{ft}$. had melted and undermined the névé (Fig. 2, p. 599). But the ice cliffs on the south side of the lake had not melted back in this way, since they were protected by ash and rock resting against them. Thus, it appears to Mr. Rose, the old outlet through an ice cave was prevented from forming, and the lake level allowed to rise until the dam gave way on Christmas Eve last.

What is quite evident is that it was the bursting of its barrier at the lowest notch in the crater rim south of the Pyramid on 24 December, 1953, and the sudden outlet of the lake water, that was the cause of the flooding of the Whangaehu River, with its load of volcanic mud and boulders, which travelled a total distance of 25 miles $(40 \mathrm{~km}$.) to Tangiwai. But initially two points were not clear: (I) whether renewed volcanic activity had played any part in causing the sudden collapse of the barrier, and (2) if the latter consisted predominantly of névé and had thus been melted through. It can be said at once that the report of Mr. James Healy, of the New Zealand Geological Survey, before the Board of Inquiry on the Tangiwai Disaster ${ }^{3}$ (cited briefly in The Times (London) of I I May I954), stated categorically that there was no evidence of actual volcanic or earthquake disturbance to bring about the collapse of the lake barrier so as to allow the release of the large body of water that formed the destructive "lahar," or mud and boulder flow, in the lower reaches of the Whangaehu River. ("Lahar," incidentally, is a Javanese term, increasingly in use, which refers to a torrential mudflow that is caused by the bursting of a volcanic crater lake, or by the melting of snow and ice by volcanic heat, or by the action of rain on ash deposited on the steep flanks of volcanoes.) However, the seismograph housed at the Château Tongariro did record vibrations, which were presumably caused by the rush of great volumes of water down the Whangaehu River; these occurred just after 20.00 hr. on 24 December. Mr. Healy has therefore suggested that, as a result of crevassing movements in the ice, or firn, the ash barrier alongside the previously existing ice cave suddenly collapsed about $20.00 \mathrm{hr}$. on that date, and precipitated a mass of water and debris down the channel beneath the ice.

Now it was not until May last, when en route to the Science Congress at Auckland, that I was able to pay a profitable visit to Ruapehu, and climb the north-north-west side of the mountain from the Château Hotel in Tongariro National Park. An earlier ascent by my wife and myself in $195^{2}$ had been abortive owing to bad weather. But this time we had two successive days on the mountain under brilliant conditions, and were enabled to make a number of observations (Fig. 3, p. 600). Elsewhere, incidentally, I have given a more general account of Ruapehu from a mountaineering point of view. ${ }^{4}$ The ascent, incidentally, from the Chateau at $37 \mathrm{IO} \mathrm{ft}$. ( $\mathrm{r} 30 \mathrm{~m}$.) involves motoring (for the lazy!) up to an altitude of about $5_{100} \mathrm{ft}$. (I554 $\mathrm{m}$.) by the skiers' road, 
which leaves some $2000 \mathrm{ft}$. $(600 \mathrm{~m}$.) of easy scrambling and walking to a point near the snout of the Whakapapa Glacier, at an elevation of about $7000 \mathrm{ft}$. $(2130 \mathrm{~m}$.) (Fig. 4). It is of interest that this glacier, like others on the mountain, would appear quite clearly to be in a state of slow shrinkage; but according to Mr. L. O. Krenek, of Wanganui, it has not shown such evidence in recent years of terminal retreat as have other glaciers on the mountain. Its present length is scarcely more than one mile $(\mathrm{I} .5 \mathrm{~km}$.), measured from the col at $8600 \mathrm{ft} .(262 \mathrm{I} \mathrm{m}$.) on the rim of the crater.

As to existing indications of the maximum advance of these glaciers during or since the Pleistocene Epoch, there are no polished rocks to be found lower than about $6000 \mathrm{ft}$. (1830 m.) on the northern side of Ruapehu, well below the Whakapapa Glacier. Moreover, moraines are conspicuous by their absence; and only in the case of the Waikato (or Mangatoetoenui) Glacier, on the eastern side of the mountain, are there clear signs of old moraines, terminal or otherwise. Indeed, Mr. Krenek informs me that the Waikato Glacier has no indications of a lower elevation of earlier glacierization than in the case of the Whakapapa Glacier. The compact and massive character of the lava rocks, varying in composition from basalt to hypersthene-andesite, may be the chief factor which inhibits fragmentation and the formation of more than a minimum of morainic material. But another factor is no doubt the sluggishness as well as the thinness of these névé, rather than true glacier, masses on all flanks of Ruapehu. The surface of the Whakapapa Glacier is noticeably even and unbroken by bergschrunds or crevasses, the only marked features being patches of ash and scoriae, often elevated somewhat above the surrounding surface, and sometimes taking the form of dirt-cones. These were mainly of the usual variety with ice cores, the result of extensive ablation on the sunny northern aspect of the mountain; whilst a few cones, or dissected ridges, could be seen to be associated with cracks that appeared to be small thrust planes in the ice bringing dirt to the surface, such as those exemplified by Mr. W. V. Lewis on the Vatnajökull of Iceland. ${ }^{5}$ It must be admitted, however, that there was little, if any, evidence otherwise of shearing stress along discrete thrust planes within the relatively inert Whakapapa névé-mass.

With reference to the question of the Pleistocene snow line in New Zealand, there is climatic and biological evidence, as R. W. Willett has shown, ${ }^{6}$ to indicate that it stood some 3900 to $4000 \mathrm{ft}$. (I I90 to $1220 \mathrm{~m}$.) lower than at present. On Ruapehu the present regional snow line is at an altitude of about $8200 \mathrm{ft}$. $\left(245^{\circ} \mathrm{m}\right.$.), whereas formerly, on the above cited evidence, it is estimated to have been as low as $4400 \mathrm{ft}$. ( $1340 \mathrm{~m}$.) in the central volcanic massif of the North Island. However, there is no existing morphological evidence in this area known to me to indicate that actual glaciers descended to anything like so low an altitude. But any such evidence, whether of glaciers or névé only, have been obscured by later lava flows and ash showers.

From the col at the head of the Whakapapa Glacier (Fig. 5), or preferably from the Dome (or Patatua, $8700 \mathrm{ft}$., $2652 \mathrm{~m}$.) above it, looking southward one can obtain a commanding and impressive view of the very beautiful crater lake, backed as it is by the highest serrated portion of the crater rim, which culminates in the peak of Tahurangi $(9175 \mathrm{ft}$., $2967 \mathrm{~m}$.). The variably greenish-blue water, streaked with sulphurous scum, is enclosed by steep banks of snow and scoriae on the northern and southern sides, whilst cliffs of névé, inter-bedded with ash, drop some $5^{\circ}$ or $60 \mathrm{ft}$. ( 15 to $18 \mathrm{~m}$.) along its western margin. On the second day's visit last May, I decided to make my way round to the lake outlet over the top of Tahurangi, which in the result involved me in an interesting ice and rock climb, and a superb view westward some 80 miles (129 km.) to the symmetrical cone of Mt. Egmont $(8260 \mathrm{ft}$., $2518 \mathrm{~m}$.), New Zealand's "Fujiyama." Another impressive object, displaying itself at intervals during the day, was Mt. Ngauruhoe (7515 ft., $2290 \mathrm{~m}$.) about to miles $(\mathrm{I} 6 \mathrm{~km}$.) away to the north-east. This, New Zealand's only ordinarily active volcano, was intermittently erupting in a series of gas-explosions and lava-emissions, and projecting at times a magnificent mushroom-like column of smoke, as of an atomic bomb, several thousand feet above the summit (Fig. 6). There is, incidentally, no known connection in the cycle of Ngauruhoe's activities and the very infrequent eruptions of Ruapehu. 
Arrived in the vicinity of the outlet of the crater lake and the head of the Whangaehu Glacier, I found myself on slopes of ash-laden névé, a good deal broken, but not deeply crevassed, at this the lowest part of the crater rim. In descending the steep icy slopes on the exterior of the rim, it was evident that the lake water was at that time issuing through a tunnel in this dirt-choked névé, and over a bar of solid lava and/or scoriae. Thence it plunged down a chasm, formed by the collapse of the névé cover, and so disappeared beneath the main mass of the Whangaehu Glacier. The interesting photograph of this chasm (Fig. 7) (for which I am indebted to Mr. Krenek) and especially the névé wall beyond, shows by the well-marked folding and faulting the stresses which have been induced in this portion of the névé-dam; but how much may have been due to the pressure of the lake water at its higher stand it is difficult to say. It would seem more likely to be evidence of the constricted movements and adjustments of parts of the névé mass as they gravitate downwards through the gap between the Pyramid and Tahurangi. In any case it would appear to have been the settlement (by compaction), movement and crevassing (strictly "schrunding") of the mixed névé and ash on the crater rim at this point that released the waters of the lake which had, for an unknown period, became pent-up above the sill, or lip, of solid lava. Then, when critical pressure had been exceeded, or progressive melting and seepage had taken place, or both, the dam must have finally given way on Christmas Eve. From correspondence, however, with Mr. Healy I gather it is his view that the barrier of lava and scoriae may have been weakened by subglacial erosion, a conclusion that I find difficult to accord with the local disposition of lava, ash and névé, apart from the fact of the sudden collapse of the dam that caused the catastrophe.

I should add that from Dr. J. W. Glen, of Cambridge, I received an interesting enquiry as to whether the break-out from the lake might not have been due to purely hydrostatic forces, brought about by a mechanism which would correspond to what has been postulated for the outbreak of such glacial lakes as Grimsvötn and Graenalón in Iceland, and also Tulsequah in British Columbia, situated in the region of the Juneau Ice Field. 7 The mechanism envisaged by Dr. Glen implies a column of water of anything from 150 to $200 \mathrm{~m}$. in depth in ice, which would cause the outbreak. However, as stated above, the greatest known depth of Ruapehu's crater lake is not more than about $78 \mathrm{~m}$, and, moreover, there is evidence that it is, and was, contained entirely in rock, except for the top $8 \mathrm{~m}$. approximately, prior to the last outbreak. On the hydrostatic theory, if it had been contained solely by ice the lake would have emptied completely. Actually the level dropped by the above amount of $8 \mathrm{~m}$. only after the catastrophe. Nor, of course, is the hypothesis of Thorarinsson, ${ }^{8}$ for the glacial lakes on Vatnajökull, in Iceland, applicable here, namely that the ice barrier of the lake might be raised by floatation and so allow escape of the pent-up waters. In this connection it is, perhaps, of interest to mention that in Thorarinsson's view the outflow from these Icelandic lakes, which is accompanied by earth-tremors, is not actually engendered by volcanic action, since the peak of the outburst precedes the tremors. On the contrary, it would seem that, in certain cases at least, the glacial lake-bursts are the specific cause of volcanic eruptions. In other words, the great release in pressure caused by the emptying of a lake may be sufficient to start a subglacial, or sub-lacustrine, eruption. Moreover, it would seem possible that under suitable conditions of contained water, and its subsequent cataclysmic break-out by whatever trigger mechanism of seepage and pressure release, or seismic tremors inducing faulting of névé or rock, the crater lake of Ruapehu might well initiate an eruption. As to simple pressure release, Mr. Healy (in a letter) admits that under certain conditions this might be possible, but that such an event would, in his opinion, only be secondary in the normal volcanic habits and the cyclic phases which Ruapehu as well as Ngauruhoe have independently shown. Another trigger mechanism, incidentally, which has been suggested is lunar tidal action, since a definite relationship has been noticed over a number of years, between the eruptions of both Ruapehu and Ngauruhoe and the new and full phases of the moon. The theory, of course, is that the extra tidal pull at such phases is sufficient to cause the lava to rise, and at times emerge and spill over the crater rim.

With regard to the actual volume of water released from the crater lake on Christmas Eve, the 
Report of the Board of Inquiry stated that the estimated discharge varied from a maximum flow of about $30,000 \mathrm{cu}$. ft. $\left(850 \mathrm{~m} .{ }^{3}\right)$ to $\mathrm{I}_{3}, 000 \mathrm{cu}$. ft. $/ \mathrm{sec}$. during the first $20 \mathrm{ft}$. $(6 \cdot \mathrm{I} \mathrm{m}$.) fall of the lake. The inspecting engineer of the Ministry of Works estimated that this initial fall took place in I 50 minutes, and that the remaining $6 \mathrm{ft}$. ( $1.8 \mathrm{~m}$.) (of the total drop of $26 \mathrm{ft}$.) then discharged comparatively slowly. As Dr. Glen has observed in his letter to me, these figures indicate a comparable rate of discharge, at peak, with those reported for Graenalon in Iceland, but on the other hand, a very much smaller total outflow than in the case of the latter, due no doubt to differences in size, configuration, and nature of outlet channel. It was the opinion of an eminent German scientist, Dr. B. Friedlaender, ${ }^{9}$ who visited Ruapehu in 1896 , that the lake mostly acted as a steam condenser hiding and absorbing to some extent its eruptive activity. That a somewhat delicate balance existed in the emission of steam and gases and the melting of névé to form the lake was indeed much emphasized by him. For he regarded Ruapehu, at least at the time of his visit, to be fully as active as nearby lake-less Ngauruhoe without appearing to be so. Here at least in the case of Ruapehu we have perhaps a miniature, yet analogous and significant instance of the great conflict between the elemental forces of water-cum-frost and fire, of which Iceland provides so many notable examples, and, within its one thousand years of history, not a few resulting catastrophes.

MS. received Io November 1954

\section{R E F E R E N C E S}

I. Beetham, George. The First Ascent of Mount Ruapehu, N.Z., and a Holiday faunt to Mounts Ruapehu, Tongariro and Ngauruhoe. Privately printed, London, Harrison \& Sons, 1926.

(However, it should be noted that the actual first ascent of one or other of the summits of Ruapehu appears to have been made in the late $185^{\circ}$ 's, or early I 860's, by Sir George Grey, who initially experienced great difficulties, as had others, on account of the tapu placed on the mountain by the Maoris; vide New Zealand Alpine Fournal, Vol. 2, I 895, p. 75 ).

2. Rose, J. H. The Crater Lake, Mount Ruapehu. Nequ Zealand Alpine Fournal, Vol. 15, No. I, I954, p. 539.

3. Tangiwai Railway Disaster. Report of Board of Inquiry. R. E. Owen, Government Printer, Wellington, April 1954.

4. Odell, N. E. Mount Ruapehu, New Zealand. Alpine Fournal, Vol. 60, No. 290, 1955, p. 103-1 2

5. Lewis, W. V. Dirt cones on the northern margins of Vatnajökull, Iceland. Fournal of Geomorphology, Vol. 3, 1940, p. $16-26$.

6. Willett, R. W. The New Zealand Pleistocene snow line, climatic conditions, and suggested biological effects. New Zealand Fournal of Science and Technology, Section B, Vol. 32, No. 1, 1950, p. I8-48.

7. Glen, J. W. The Stability of Ice-Dammed Lakes and Other Water-Filled Holes in Glaciers. Fournal of Glaciology, Vol. 2, No. 15, 1954, p. 316-18.

8. Thorarinsson, S. Some new aspects of the Grimsvötn problem. Journal of Glaciology, Vol. 2, No. 14, 1953, p. 267-75. 9. Friedlaender, B. Some notes on the volcanoes of the Taupo district. Transactions of the New Zealand Institute, Vol. $3 x, 1898$, p. $498-510$.

Professor Odell has sent the following letter from Mr. L. O. Krenek, dated ${ }_{5}$ March 1955 , which gives further information about the rapid retreat of the glaciers in North Island, New Zealand:

... You may have read already of the great changes which have taken place on the northern slopes of Ruapehu. I have not seen anything like it anywhere else. The glaciers of Ruapehu are simply collapsing. The Whakapapa has receded 75 yards since last year, and enormous areas of rock have emerged. Hundreds of crevasses have opened up and the area is so badly crevassed that it is difficult to find a route to the Crater Lake. Over a considerable part of the glacier the ash of the 1945 eruption is now exposed, often one foot deep. . . . The melt waters cut this layer of ash into longitudinal ridges; the horizontal crevasses, which open up everywhere, cut these ridges at right angles, so that hundreds of black hummocks are formed. A little further downstream ablation has proceeded far enough for the development of dirt cones. There are hundreds and hundreds of them. I have never seen anything like it. I was up there at the beginning of February for the last time. Since that time we have had much hotter weather and I hear that the situation has deteriorated considerably since then $* . .$. I really think the development is quite unique, because it came so suddenly.

... The level of the Crater Lake has dropped two or three feet, although last year's ice cave is completely closed. We visited the old outlet into the uppermost Whangaehu. We found a waterfall, more or less at the same place. 'Twice or perhaps three times as much water was discharged. All the remnants of ice sticking to the southern slope of the Whangaehu glacier... have disappeared completely. So far I have not had an opportunity of re-visiting the snouts of the Whangaehu and Waika to glaciers, but I could see that they are similarly affected like the Whakapapa, but dirt cones are less numerous.

In January I visited the southern glacier, Mangaehuehu. There was no ash exposed (less ablation?) but there is a very well marked lateral moraine, nearly $250 \mathrm{ft}$. above the present level. In appearance it looks like the 1850 moraines of the Alps. The terminal moraines are about 500 to $600 \mathrm{yd}$. from the present end. One man from Ohakune, whom I met there, promised to take photographic panoramas from a certain point at regular intervals, so that it would be possible to follow the behaviour of this glacier.

* Later information from Mr. Krenek makes the total recession since last year roo yd. 